OPEN ACCESS

Edited by:

Davide Tiranti,

Agenzia Regionale per la Protezione Ambientale (ARPA), Italy

Reviewed by:

Fernando Gazquez,

University of Almería, Spain Ilenia M. D'Angeli,

University of Bologna, Italy

*Correspondence:

Leonardo Piccini

leonardo.piccini@unifi.it

Specialty section:

This article was submitted to Quaternary Science, Geomorphology and Paleoenvironment, a section of the journal Frontiers in Earth Science

Received: 26 February 2021 Accepted: 23 April 2021

Published: 20 May 2021

Citation:

Piccini L, Nannoni A,

Costagliola P, Paolieri M and Vigiani $C$ (2021) Composition and Structure of Phosphate-Rich Parietal Crusts and Nodules in Monte Corchia Cave,

Alpi Apuane (Central Italy).

Front. Earth Sci. 9:673109.

doi: 10.3389/feart.2021.673109

\section{Composition and Structure of Phosphate-Rich Parietal Crusts and Nodules in Monte Corchia Cave, Alpi Apuane (Central Italy)}

\author{
Leonardo Piccini*, Alessia Nannoni, Pilario Costagliola, Mario Paolieri and \\ Chiara Vigiani
}

Department of Earth Science, Università Degli Studi di Firenze, Florence, Italy

Cave environment allows long-term processes of rock weathering and chemical deposition that cannot occur on Earth surface directly exposed to meteoric and external biochemical agents. Apart from the common carbonate speleothems, chemical precipitation from infiltration water can also produce phosphate-rich formations usually occurring as parietal dark crusts or spheroidal nodules. Despite the potential purposes of these kind of deposits as paleoenvironmental proxies, they have been still poorly investigated by cave scientists. Monte Corchia cave (NW Tuscany, Central Italy) is one of the most studied caves in the world, particularly for paleoclimate reconstructions from calcite speleothems. Several samples of parietal formations were collected in relict phreatic and epiphreatic passages at different altitudinal levels that reflect different evolutionary stages of this large cave system. Samples were analyzed by diffractometry and SEM-EDS possibly revealing the occurrence of hydroxyapatite or fluorapatite mixed with Fe/Mn incrustations and allogenic clastic particles. Crusts often cover the entire section of relict phreatic or epiphreatic passages and can be related to precipitation during waterfilled phases. Phosphate nodules are almost entirely composed by hydroxyapatite or fluoroapatite and could be the result of long-term chemical (or bio-chemical) precipitation in air-filled environments.

Keywords: karst, cave deposit, speleothem, Apuan Alps, apatite group

\section{INTRODUCTION}

Caves are highly conservative environments where the effects of surface processes (concerning climate, hydrology, morphology, biology, etc.) reveal themselves in depositional records that can be either clastic (alluvial deposits) or chemical (speleothems). Calcite speleothems are the most studied formation of chemical origin in caves since their capability to provide key paleo-environmental information and for the possibility to be accurately dated. Other types of cave deposits are still poorly studied, although potentially interesting as paleo-environmental proxies. Among these are gypsum crystals (Gázquez et al., 2013, 2020) and other uncommon speleothems such as Fe and Mn oxide deposits (e.g., Rossi et al., 2010; Frierdich et al., 2011). 
Beyond carbonates and sulfates, phosphates are among the most frequent minerals in caves (Hill and Forti, 1997). Commonly, they are the product of chemical reactions between guano, bones or other animal residues and cave bedrock, calcite concretions or sediments (e.g., Audra et al., 2019, and references therein). Among the most frequent phosphates we can find brushite or more commonly the minerals of the apatite group (mainly hydroxyapatite or fluorapatite) and other less common phosphates, including: taranakite, ardealite, variscite, etc. (e.g., Fiore and Laviano, 1991; Onac et al., 2001). The phosphates associated with guano accumulation often form deposits of considerable thickness that have been the object of excavation to obtain fertilizers (Frank, 1998; Audra et al., 2019). However, phosphates are often found also in caves where there are no relevant deposits of guano, usually occurring in the form of thin patinas or crusts that cover the rock or cave deposits, or as small spheroidal nodules grown on the walls (Onac and Forti, 2011; Audra et al., 2019).

Very promising results were obtained also from Fe/Mn crusts deposited in water-filled cave passages (e.g., Gázquez et al., 2011). The authors linked the genesis of the crusts that coat the cave walls to the alternation between phreatic and epiphreatic conditions. $\mathrm{Fe}$ and $\mathrm{Mn}$ mobilization were related to anoxic conditions during submerged phases, whereas $\mathrm{Fe}$ and $\mathrm{Mn}$ oxidation occurred in aerobic, bacteria-mediated, conditions during epiphreatic phases. Other ferromanganese deposits were related to the switch between phreatic and vadose conditions. Therefore, flow conditions exert a pivotal role on the formation of these deposits. In such perspective, our contribution presents a preliminary investigation on another peculiar type of crusts or thin patinas covering the rock walls of inactive karst conduits of the Monte Corchia cave system in the Alpi Apuane (NW Tuscany, Italy; Figure 1). Various types of dark-colored parietal coatings and crusts were recognized in several relict passages of this wide karst systems (Piccini, 2011). In a previous work, Piccini et al. (2005) mentioned the presence of these deposits. Successively, a pilot study (Mantelli et al., 2015a) reported the results of chemical analyses carried out on black patinas collected in the Corchia cave. The Monte Corchia karst complex has been the subject of very detailed studies concerning speleothems and paleoclimatic records since some decades (e.g., Drysdale et al., 2004, 2009; Drysdale et al., 2020; Zanchetta et al., 2007; Piccini et al., 2008; Regattieri et al., 2014). In this research instead, attention has been focused on: (i) a particular type of crusts that cover the wall of ancient phreatic or epiphreatic passages and, (ii) some nodules found in limited sectors of relict phreatic passages. Both deposits are described from a textural and mineralogical point of view along with their possible origin and environmental meaning.

\section{MATERIALS AND METHODS}

\section{Sampling Site}

The Alpi Apuane represent a tectonic window where the Tuscan Metamorphic Units outcrop (Carmignani and Kligfield, 1990;
Molli and Vaselli, 2006 and references therein). The Paleozoic basement consists mainly of phyllites and metarenites (Conti et al., 2019). The Mesozoic cover includes Triassic continental to shallow water deposits followed by Upper Triassic-Lower Jurassic carbonate platform sediments ("Grezzoni” dolostones, dolomitic marbles and marbles). The platform meta-sediments are followed by cherty meta-limestones, cherts and calcschists, phyllites, calcschists and meta-arenites from Upper Jurassic to Oligocene. The most important karst features of this area consist of several cave systems among which the Corchia cave surely is the most studied and worldwide known. The Corchia karst system (Figure 1) is about seventy $\mathrm{km}$ long and 1,185 $\mathrm{m}$ deep and it is at the present time one of the largest and deepest caves in Italy. The system is characterized by different levels attributed to a multiphase lowering of the base level occurred during the past 2-2.5 million years (Piccini, 2011; Isola et al., 2021).

In several sector of this cave, different kinds of dark incrustations occur on the conduit walls (Figure 2). In most cases, they were formed on the surface of the bedrock or on clastic deposits and they are easy to remove because they usually lay on deeply weathered rock surfaces. Thin black patinas were also observed over some speleothems, but they have not yet been sampled because they cannot be collected without damaging calcite formations and without specific coring tools. Fourteen samples were collected in 8 different sites located in the three major levels of relict horizontal passages located around 1,400, 1,150, and $870 \mathrm{~m}$ above the present sea level (Figure 1), which are considered as formed during three major evolutionary stages of this karst system (Piccini, 1998, 2011). The most common type of sample has the appearance of a crusts, usually 1-3 $\mathrm{mm}$ thick and from dark to light brown colored, that directly cover the bedrock (Figures 2A-1,B-1). Another kind of samples is represented by small $(1-3 \mathrm{~cm})$ spheroidal nodules hanging from the rock wall (Figure 2C-1). The latter are very dark in color or almost black and show a smooth and bright surface. The dark crusts are found with greater frequency in the upper and oldest sectors of the Corchia system, on rock walls of phreatic or epiphreatic conduits, or on isolated blocks. The crusts often coat typical scallops flow morphologies and are in turn covered by remnants of alluvial deposits. Their presence appears concentrated on surfaces that are always very altered and never fresh-looking. Nodules are much less frequent and are concentrated in limited sectors of the cave of different origin, often grown in niches or hollows on the walls and never exposed to direct dripping.

\section{X-Ray Diffraction (XRD)}

Five samples of coatings and one sample of a nodule were prepared for X-ray diffraction by powdering in an agate mortar and then analyzed at Centro di Servizi di Cristallografia Strutturale - Università di Firenze (CRIST) with a D8 Advance (Bruker) diffractometer operating with a $\mathrm{Cu} \mathrm{X}$-ray source, a Theta-Theta goniometer, and a flat Eulero Cradle sample holder, equipped with a Bruker LYNXEYE-XE detector. The filament current of the tube was $40 \mathrm{~mA}$ and the acceleration potential $40 \mathrm{kV}$. Yttrium oxide $\left(\mathrm{Y}_{2} \mathrm{O}_{3}\right)$ was used as a reference material. Other patinas' samples were too thin (thickness $<0.3-0.5 \mathrm{~mm}$ ) 

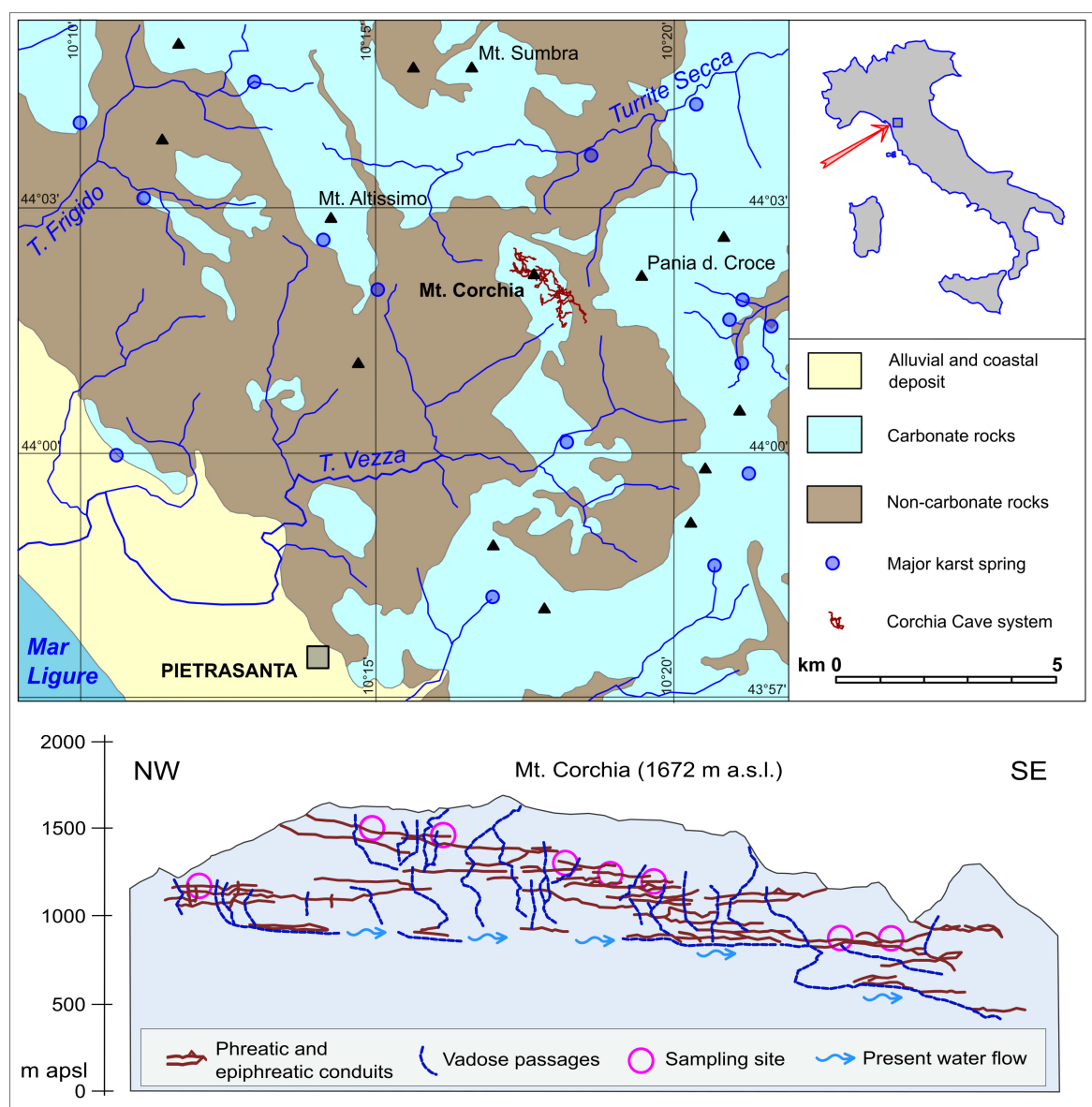

FIGURE 1 | Location map of Mt. Corchia area and schematic longitudinal profile of Corchia cave system with the position of sampling sites.

and were not analyzed because we were not able to obtain enough material for standard XRD analyses.

\section{Scanning Electron Microscopy and Microanalysis (SEM-EDS)}

Fourteen small fragments coming from all the eight sampling sites were analyzed through SEM-EDS. The fragments of crusts, nodules, and dark patinas of about $1-2 \mathrm{~cm}^{2}$ were fixed to half inch aluminum stubs with a graphite rubber and then coated by graphite sputter. Semi-quantitative standardless microchemical analyses were performed by means of a Scanning Electron Microscope (SEM) ZEISS EVO MA15 (operating at $15 \mathrm{kV}$ acceleration voltage), coupled with an Energy Dispersive Spectrometer (OXFORD INCA 250 EDS detector and software INCA 250, Oxford Instruments ${ }^{\circledR}$ ) at the Centro di Microscopia Elettronica e Microanalisi (MEMA) of the Florence University. About 25-30 EDS micro-analyses were performed for each sample to chemically characterize major and minor components, for a total of about 300 punctual micro-analyses. In the crust, EDS analysis was preferably targeted to the three major components: clastic particles, matrix, and secondary incrustations. In the nodules, analysis was directed to their external surface (Figure 2C-2) and to cross-cut polished sections (Figure 2C-3).

\section{RESULTS}

The collected samples are largely attributable to three types of coatings. Eight samples are in the form of thin crusts ranging in color from light to dark brown, with a rough surface and arranged over large areas covering entire sectors of the wall or sediments in conduits of phreatic origin. These crusts are extremely friable and easily detach from the rock which appears deeply altered (decemented) for a few mm of thickness. Four samples appear as thin patinas with a glossy appearance and a dark brown color strongly attached to the rock. These patinas are found on the rock walls of passages that may have also undergone remodeling by epiphreatic conditions. The third kind is instead made up of nodular formations irregularly distributed in localized spots on the rock walls and ceilings of certain passages of various origins but never on recent surfaces, such as those due to collapse.

XRD analyses indicate that most of the samples are mainly composed of minerals belonging to the apatite group, but it was not possible to discriminate between hydroxyapatite 

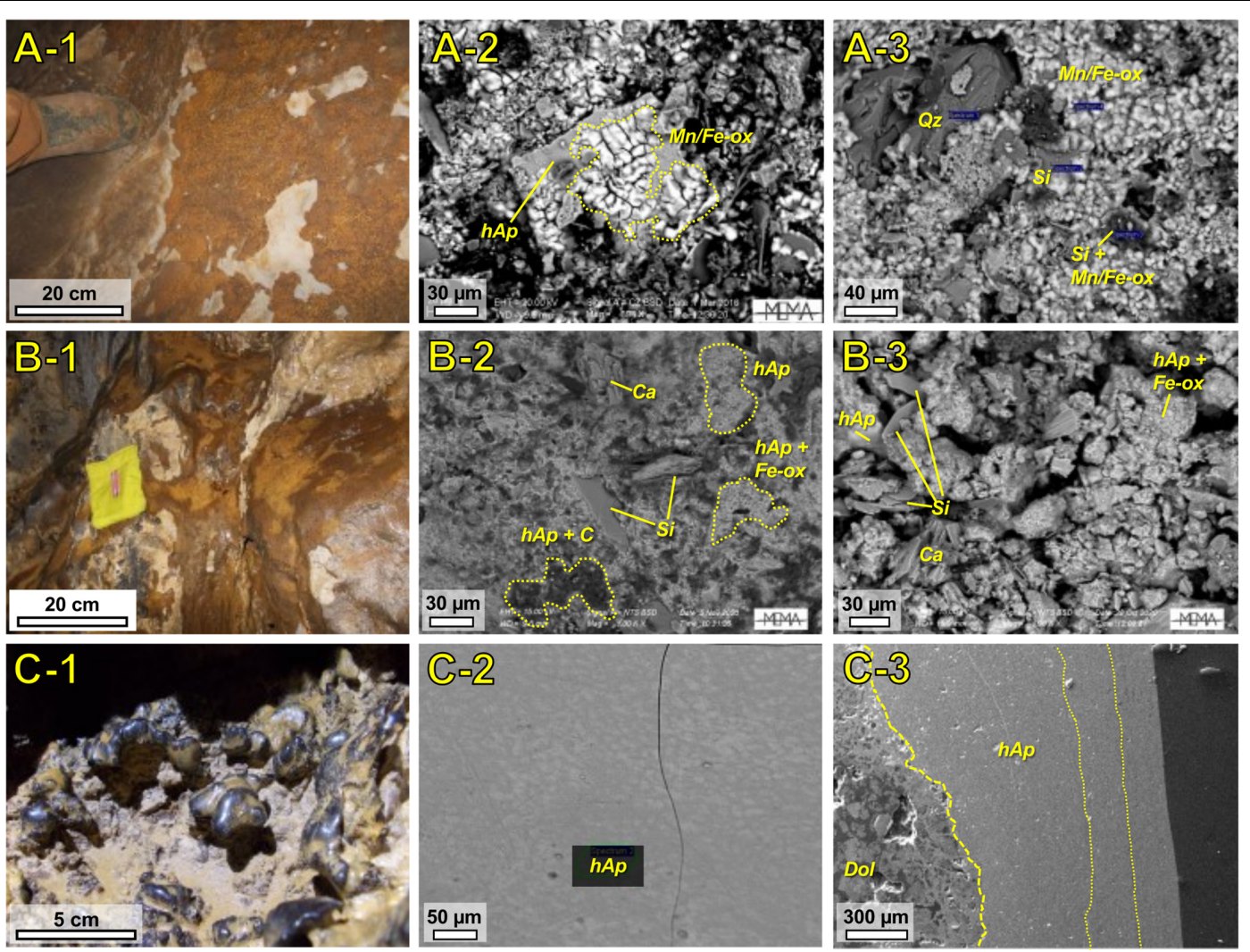

FIGURE 2 | (A-1) Brown parietal crusts on the wall of a relict phreatic passage at 1,200 m a.s.l. (A-2,A-3) SEM-BSE images of sample A-1 showing clasts of different nature $(\mathrm{Qz}=$ quartz, $\mathrm{Si}=$ silicate) covered by hydroxyapatite (hAp) and Fe/Mn incrustations (light areas, Mn/Fe-ox). (B-1) Brown parietal crusts on the wall of a relict phreatic passage at 1,400 m asl. (B-2,B-3) SEM-BSE images of sample B-1 showing clasts of different nature (Ca $=$ calcite) cemented by apatite and Fe/Mn incrustations (light areas). (C-1) Calcium phosphate nodules on the wall of a relict phreatic passage collected in the Corchia cave at 1,200 $\mathrm{m}$ asl. (C-2) SEM-BSE images of sample C-1 showing its external regular surface consisting of hydroxyapatite. (C-3) Cross section of the nodule showing a regular structure roughly laminated (fine yellow dotted lines) grown on altered dolomite bedrock (yellow dashed line = bedrock/crust interface).

$\left[\mathrm{Ca}_{5}\left(\mathrm{PO}_{4}\right)_{3} \mathrm{OH}\right]$ and fluorapatite $\left[\mathrm{Ca}_{5}\left(\mathrm{PO}_{4}\right)_{3} \mathrm{~F}\right]$. Muscovite $\left[\mathrm{KAl}_{2}\left(\mathrm{Si}_{3} \mathrm{Al}\right) \mathrm{O}_{10}(\mathrm{OH}, \mathrm{F})_{2}\right]$ is the most abundant silicate. Traces of birnessite $\left[(\mathrm{Na}, \mathrm{Ca}, \mathrm{K})_{\mathrm{x}}\left(\mathrm{Mn}^{4+}, \mathrm{Mn}^{3+}\right)_{2} \mathrm{O}_{4} \cdot 1.5\left(\mathrm{H}_{2} \mathrm{O}\right)\right]$ were recognized in three samples as well. One sample consists mostly of calcite $\left[\mathrm{CaCO}_{3}\right]$ and/or dolomite $\left[\mathrm{CaMg}\left(\mathrm{CO}_{3}\right)_{2}\right]$ and secondarily of muscovite, quartz $\left[\mathrm{SiO}_{2}\right]$, and a minor amount of hydroxyapatite.

SEM back scattered electrons (BSE) images shows that crusts consist of fine clastic particles cemented and often partially covered by a porous precipitation matrix. Clastic grains are rarely larger than $30 \mu \mathrm{m}$ and are mainly composed of $\mathrm{Si}$ and $\mathrm{Al}$, with minor amounts of $\mathrm{K}, \mathrm{Na}$ and $\mathrm{Mg}$. Clastic particles of calcite and $\mathrm{Fe} / \mathrm{Mn}$ oxides/hydroxides (probably goethite and birnessite) are also present in some samples, although in a minor number respect to silicates. Chemical micro-analyses and morphological features suggest that the silicate grains are compatible with the phyllosilicates group and are probably made up of muscovite (Figure 2B-3). Matrix is easily distinguished in SEM-BSE images, since it appears of a light gray color whereas silicate clastic minerals are darker. The latter appear to be anhedral, often with an irregular shape, further evidencing their clastic nature. Matrix is generally composed of $\mathrm{P}$ and $\mathrm{Ca}$ as major constituents and often appears as an irregular layer wrapping the clastic grains (Figure 2A-2). $\mathrm{P}$ and $\mathrm{Ca}$ are sometimes accompanied by minor amounts of $\mathrm{F}$, whereas $\mathrm{Cl}$ was not detected in any sample. This suggests that the phosphate minerals found in the samples are probably fluorapatite and hydroxyapatite, whereas chlorapatite is not present. Phosphatic nodules show a regular and uniform structure both on their smooth external surface (Figure 2C-2) and in their cross section (Figure 2C-3). In the crusts, apatite is usually in association with other phases, notably $\mathrm{Fe}$ and $\mathrm{Mn}$ oxides/hydroxides (with minor amounts of $\mathrm{Al}$ and $\mathrm{Si}$, the latter being probably indicative for quartz), that locally may be more abundant forming irregular and nodular incrustations. The close textural interconnection between $\mathrm{Mn} / \mathrm{Fe}$ patinas and apatite is reflected by micro analyses where $\mathrm{Mn}$, $\mathrm{Fe}, \mathrm{P}$ and $\mathrm{Ca}$ are always strictly associated as the result of the physical fine juxtaposition between these two mineralogical phases. Very dark areas in SEM-BSE images are observed as well. Micro-analyses reveal that the latter contain very low concentrations of $\mathrm{Al}, \mathrm{Mg}, \mathrm{Ca}, \mathrm{Fe}$ whereas $\mathrm{C}$ (partly due to the sample graphite coating) and $\mathrm{O}$ are always the major constituent. This suggests that the dark areas may represents remnants of precipitated organic matter. 


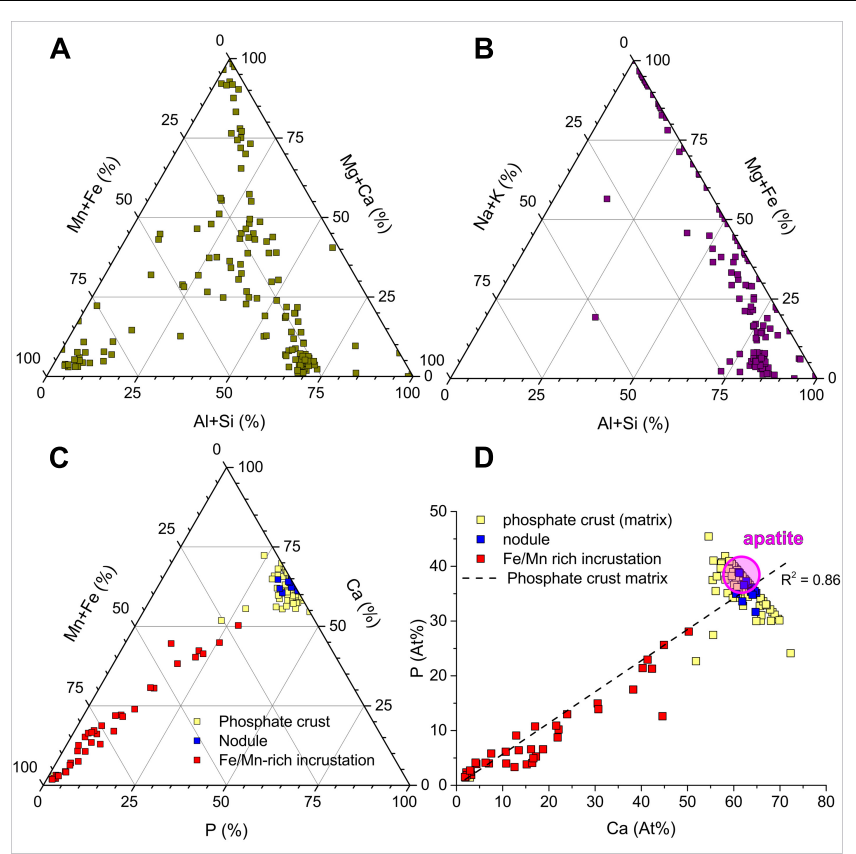

FIGURE 3 | (A) Ternary diagram showing the relative atomic\% of $\mathrm{Al}+\mathrm{Si}$, $\mathrm{Mg}+\mathrm{Ca}$ and $\mathrm{Mn}+\mathrm{Fe}$ fractions of the clastic grains enclosed in phosphate crusts; (B) ternary diagram showing relative atomic $\%$ of $\mathrm{Al}+\mathrm{Si}, \mathrm{Na}+\mathrm{K}$ and $\mathrm{Mg}+\mathrm{Fe}$ fractions of the clastic grains enclosed in phosphate crusts; (C) ternary diagram showing the relative atomic\% of $\mathrm{P}, \mathrm{Mg}+\mathrm{Ca}$ and $\mathrm{Mn}+\mathrm{Fe}$ fractions of the crust's matrix; (D) scatter plot of $\mathrm{Ca}$ and P atomic\% on Ca + P + Mn + Fe obtained with SEM-EDS micro-analysis of crusts' matrix: the dashed line represents the theoretical molar ratio of apatite, while pure apatite is approximately represented by the purple circle.

Figure 3 quantitatively illustrates the relative proportions of the major elements in all the micro-analyses of crusts and nodules either for their clastic (Figures 3A,B) or matrix (Figure 3C) components. Figure $3 \mathrm{~A}$ clearly indicates the occurrence of three groups in the clastic component: $\mathrm{Mn} / \mathrm{Fe}$ oxides/hydroxides at the left/down corner, carbonate close to the upper vertex, and silicates in the right/down area. Silicate clast are rarely clean, being often associate to a significant proportion of $\mathrm{Mn}+\mathrm{Fe}$ (usually about $25 \%)$. In the midpoint sector of the diagram there is a dispersed cloud of points, which probably refers to silicate clasts coated by a patina of apatite and/or $\mathrm{Mn} / \mathrm{Fe}$ oxides/hydroxides of different thickness. Figure $3 \mathbf{B}$ allows us to conclude that silicate clasts mainly consist of silicate with a low content of $\mathrm{Na}+\mathrm{K}$ : this composition is well compatible with muscovite particles.

Figure 3C shows that crust matrix and nodules mainly consist of Ca-phosphate with a $\mathrm{P} / \mathrm{Ca}$ proportion corresponding to the apatite group. Fe/Mn incrustations have variable contents of $\mathrm{Ca}$ and $\mathrm{P}$, although $\mathrm{Ca}$ is always more abundant than $\mathrm{P}$ and their sum never exceed the $75 \%$ of the $\mathrm{P}+\mathrm{Ca}+\mathrm{Mn}+\mathrm{Fe}$. Additionally, the micro-analyses of $\mathrm{Fe} / \mathrm{Mn}$ oxides/hydroxides are mostly aligned on a trend where the $\mathrm{P} / \mathrm{Ca}$ ratio is still typical of apatite. Samples are clustered either close to the $\mathrm{Mn}+\mathrm{Fe}$ vertex or in the area comprised between $\mathrm{Mg}+\mathrm{Ca}=60-85 \%$ and $\mathrm{P}=15-$ $30 \%, \mathrm{Mn}+\mathrm{Fe}=0-10 \%$. Finally, Figure $3 \mathrm{D}$ shows the $\mathrm{P} / \mathrm{Ca}$ ratio of the phosphate matrix, Fe/Mn incrustations and phosphate nodules. Matrix and nodules are grouped in a restricted sector of the plot and aligned on a trend with an inverse correlation between $\mathrm{Ca}$ and $\mathrm{P}$ due to the virtual absence of $\mathrm{Fe}$ and $\mathrm{Mn}$; in fact, $\mathrm{P}+\mathrm{Ca}$ represents $95-100 \%$ of the $\mathrm{P}+\mathrm{Ca}+\mathrm{Fe}+\mathrm{Mn}$ content.
Pure hydroxyapatite samples fall near a P/Ca of 0,6 (purple circle in Figure 3D) whereas samples with higher $\mathrm{P} / \mathrm{Ca}$ ratios could possibly represent other phosphate minerals.

\section{DISCUSSION}

The aim of this article is primarily to describe the phosphate deposits occurring in the Monte Corchia karst system, one of the most studied caves in the world from a paleoclimatic point of view. Although performed on a limited number of samples, our research indicates that the crusts and calcium phosphate nodules (i) are exclusively found in relict conduits of phreatic or epiphreatic origin, (ii) usually cover flow dissolution forms (scallops), (iii) are often associated with silicoclastic deposits of partially allogenic nature. Calcium phosphate is mainly in form of a cement incorporating very fine silicate clastic material (usually from 5 to $20 \mu \mathrm{m}$ in diameter) and are characterized by scattered incrustations of $\mathrm{Fe} / \mathrm{Mn}$ oxides/hydroxides that possibly reflect oscillations in the water level in the cave (cf., Gázquez et al., 2011). Noteworthy, no deposits of guano and no phosphates mineralization associated with present or ancient guano accumulation are known in the Corchia karst system. In addition, present seepage waters are free of dissolved phosphates (Montigiani et al., 1998; Mantelli et al., 2015b). All these elements suggest that: (i) P in the Corchia system has an ancient and allochthonous origin, (ii) it was transported into the karst system by waters coming from the surface, and (iii) that calcium 


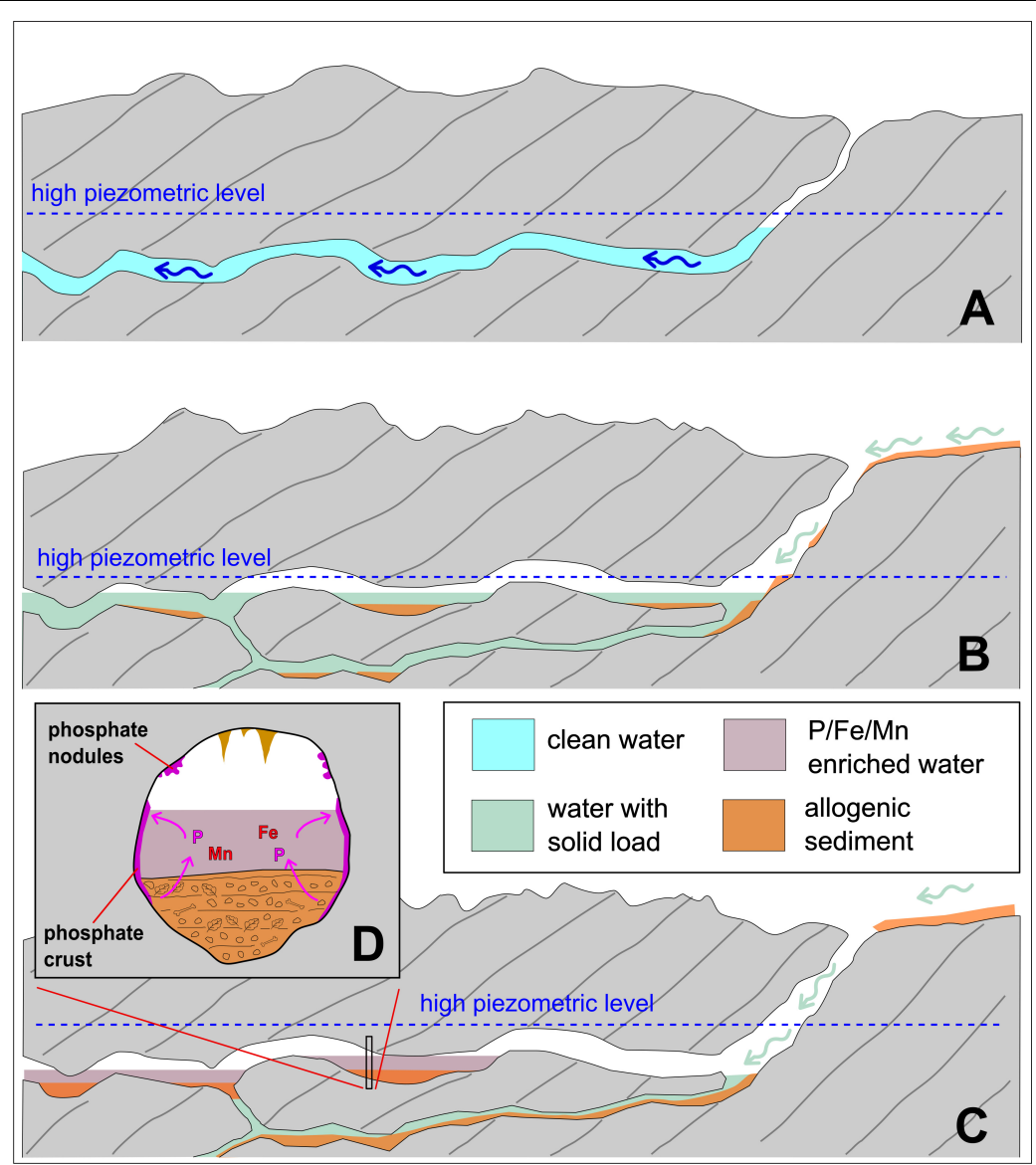

FIGURE 4 | Formation sketch of phosphate-rich crusts in the Corchia cave system. (A) Phreatic stage with no clastic load; (B) transition from phreatic to epiphreatic condition with allogenic recharge and in-filling; (C) Epiphreatic stage with abundant filling deposition and a reduction of hydraulic conductivity that caused flooding of relict phreatic conduits where stagnant water remains for prolonged time in contact with allogenic sediments. (D) P and Mn/Fe mobility from sediments to precipitation as parietal crusts.

phosphate was formed by in situ chemical precipitation in waterfilled environments with stagnant or very slowly flowing water.

Based on these observations and on the locations in which these crusts are found, it is possible to infer an evolution sketch that can be summarized in the following phases (Figure 4). The formation of large dissolution conduits in phreatic regime (Figure 4A) was followed by a gradual transition to epiphreatic conditions with the arrival of allogenic waters and sediments, probably rich in organic matter, from the surface catchment (Figure 4B). This circumstance is demonstrated by the occurrence of clastic deposits containing non-metamorphic pebbles and sand in the upper level of the Corchia cave (from 1,200 up to $1,400 \mathrm{~m}$ asl) (Piccini, 2011; Isola et al., 2021). The development of these phreatic and epiphreatic levels is ascribed to a phase of allogenic recharge that these passages have experienced in the early stages of development and that, according to Piccini $(1998,2011)$, can be traced back to the early Pleistocene (up to 2.5 million years ago). Therefore, the formation of phosphate crusts may be related to phases of high flow dominated by sediment-rich water and, reasonably, with a significant content of organic matter (mainly vegetation waste), coming from a surface basin and introduced in the karst system during flood. Actually, there are several evidences of a stage when some of the upper passages of the Corchia system were almost completely filled by allogenic sediments.

Due to the introduction into the karst system of relevant quantities of sediments, conduits were partially clogged with a following reduction of their hydraulic conductivity. Consequently, occasional, or seasonal flooding of large sectors happened, following storm events or during particularly rainy periods (Figure 4C). This flooding stage could also be associated with a rise in the base level, possibly due to the accumulation of sediments for climatic causes into the nearby valley. During the post-flooding phases, the deposition of a thin film of silicoclastic mud occurred on conduits wall. Successively, the precipitation of calcium phosphate (mainly hydroxyapatite) cemented the mud layer, whereas Fe- and Mn-rich oxides/hydroxides finally coated the phosphate crust (Figure 4D). This process could be repeated several times, forming a regular coat up to $2-3 \mathrm{~mm}$ thick on walls and isolated blocks, until the lower passages were able to allow the discharge of major floods. 
Due to the relatively low mobility of phosphate in stream water, especially those with high $\mathrm{Ca}$ content (e.g., Diaz et al., 1994; Filippelli, 2008; Oelkers and Valsami-Jones, 2008), we propend for phosphate ions to be transported and stored in form of vegetal organic matter associated to sediments or adsorbed onto $\mathrm{Fe} / \mathrm{Al}$ oxyhydroxides, as commonly observed in lacustrine environments (Golterman, 1995, 2001; Lu et al., 2016), rather than being carried in the system as dissolved compound in flowing water. In caves, due to absence of vegetation, phosphorous precipitates as apatite instead of been absorbed by plants and algae for their life cycle.

Phosphate nodules are a more enigmatic formation and we have not still elements that could shed light on their origin. Otherwise, the lack of detrital grains, their morphology and their internal structure suggest they could be the result of a concentrical aggregation of hydroxyapatite in an aired environment due to the evaporation of phosphate-rich water parietal films on more prominent points.

\section{CONCLUSION}

In the Corchia cave system, phosphate crusts are a quite common feature of relict phreatic and epiphreatic passages, often associated with remnants of allogenic sediments. XRD and SEMEDS analyses showed that the crusts consist of a phosphate matrix incorporating mainly silicate grains and often coated by $\mathrm{Fe} / \mathrm{Mn}$ oxides/hydroxides (presumably goethite and birnessite). Texture and composition of these coatings indicate an origin in an underwater environment as the result of the precipitation of phosphates and $\mathrm{Mn} / \mathrm{Fe}$ oxides/hydroxides in typical epiphreatic conditions subject to periodic flooding and with a fine solid load of predominantly silicoclastic nature. Such conditions are not compatible with the present or recent hydrologic setting, so they necessarily indicate an ancient origin. In the upper level of conduits (up to $1,400 \mathrm{~m}$ asl) the formation of phosphate crusts may be related to the phases dominated by allogenic recharge that these passages have experienced in the early stages of development and that can be traced back to the early Pleistocene.

Based on the present data, the Corchia's phosphate crusts do not appear as the product of in-site reactions of guano deposits with rock, as usually happens, but the result of parietal precipitation in stagnant water rich in organic matter. Differently, nodules consist almost exclusively of apatite, sometimes slightly contaminated by $\mathrm{Mn} / \mathrm{Fe}$. Their structure is compatible with a formation in aired environment through a regular deposition of concentric phosphate layers on walls asperities.

\section{REFERENCES}

Audra, P., De Waele, J., Bentaleb, I., Chroňáková, A., Krištůfek, V., D’angeli, I., et al. (2019). Guano-related phosphate-rich minerals in European caves. IJS 48, 75-105. doi: 10.5038/1827-806x.48.1.2252

Carmignani, L., and Kligfield, R. (1990). Crustal extension in the northern Apennines: the transition from compression to extension in the Alpi Apuane Core Complex. Tectonics 9, 1275-1303. doi: 10.1029/tc009i006p0 1275
A detailed description of chemical, and possible biochemical, reactions and processes involving sediment, water, and bedrock, and that led to the formation of this kind of deposits, is beyond the aims of this article. Nevertheless, this represents the first detailed description of an uncommon cave phosphate deposit not directly associated with guano or other animals' remnants. Despite the difficulty to investigate the origin and the formation processes of this cave deposit, it could represent a new potential proxy for paleoenvironmental and paleoclimate records and will be possibly object of further and more sophisticate analysis in a next future.

\section{DATA AVAILABILITY STATEMENT}

The raw data supporting the conclusions of this article will be made available by the authors, without undue reservation.

\section{AUTHOR CONTRIBUTIONS}

LP: research coordination, data analysis, figures drawing, and writing of the manuscript. AN: SEM-EDS, and XRD analyses, data processing, plots drawing, and writing of the manuscript. PC: data interpretation and manuscript revision. MP and CV: SEM-EDS analyses and data interpretation. All authors contributed to the article and approved the submitted version.

\section{FUNDING}

This research has been funded by Università Degli Studi di Firenze.

\section{ACKNOWLEDGMENTS}

The authors wish to thank the Parco Regionale Alpi Apuane for sampling permission and the two reviewers whose contribute improve the quality of the manuscript.

\section{SUPPLEMENTARY MATERIAL}

The Supplementary Material for this article can be found online at: https://www.frontiersin.org/articles/10.3389/feart. 2021.673109/full\#supplementary-material

Conti, P., Carmignani, L., Massa, G., Meccheri, M., Patacca, E., Scandone, P., et al (2019). Note Illustrative della Carta Geologica d'Italia alla scala 1:50,000 "Foglio 249-Massa Carrara”. Italy: Servizio Geologico d'Italia.

Diaz, O. A., Reddy, K. R., and Moore, P. A. Jr. (1994). Solubility of inorganic phosphorus in stream water as influenced by $\mathrm{pH}$ and calcium concentration. Water Res. 28, 1755-1763. doi: 10.1016/0043-1354(94)90 248-8

Drysdale, R., Couchoud, I., Zanchetta, G., Isola, I., Regattieri, E., Hellstrom, J., et al. (2020). Magnesium in subaqueous speleothems as a potential 
palaeotemperature proxy. Nat. Commun. 11:5027. doi: 10.1038/s41467-02018083-7

Drysdale, R. N., Hellstrom, J. C., Zanchetta, G., Fallick, A. E., Goñi, M. S., Couchoud, I., et al. (2009). Evidence for obliquity forcing of glacial termination II. Science 325, 1527-1531. doi: 10.1126/science.1170371

Drysdale, R. N., Zanchetta, G., Hellstrom, J. C., Fallick, A. E., Zhao, J. X., Isola, I., et al. (2004). Palaeoclimatic implications of the growth history and stable isotope ( $\delta 18 \mathrm{O}$ and $\delta 13 \mathrm{C}$ ) geochemistry of a Middle to Late Pleistocene stalagmite from central-western Italy. Earth Planet. Sci. Lett. 227, 215-229. doi: 10.1016/j.epsl.2004.09.010

Filippelli, G. M. (2008). The Global Phosphorus Cycle: past. Present, and Future. Elements 4, 89-95. doi: 10.2113/gselements.4.2.89

Fiore, S., and Laviano, R. (1991). Brushite, hydroxylapatite, and taranakite from Apulian caves (southern Italy): new mineralogical data. Am. Mineral. 76, 1722-1727.

Frank, E. F. (1998). History of the guano mining industry, Isla de Mona, Puerto Rico. J. Caves Karst Sci. 60, 121-125.

Frierdich, A. J., Hasenmueller, E. A., and Catalano, J. G. (2011). Composition and structure of nanocrystalline Fe and Mn oxide cave deposits: implications for trce element mobility in karst systems. Chem. Geol. 284, 82-96.

Gázquez, F., Bauska, T. K., Comas-Bru, L., Ghaleb, B., Calaforra, J.-M., and Hodell, D. A. (2020). The potential of gypsum speleothemes for paleoclimatology: application to the Iberian Roman humid period. Sci. Rep. 10:14705. doi: 10 . 1038/s41598-020-71679-3

Gázquez, F., Calaforra, J. M., and Forti, P. (2011). Black Mn-Fe crusts as markers of abrupt palaeoenvironmental changes in El Soplao Cave (Cantabria, Spain). Int. J. Speleol. 40, 163-169. doi: 10.5038/1827-806x.40.2.8

Gázquez, F., Calaforra, J.-M., Stoll, H., Sanna, L., Forti, P., Lauritzen, S.-E., et al. (2013). Isotope and trace element evolution of the Naica aquifer (Chihuahua, Mexico) over the past 60,000 yr revealed by speleothems. Quat. Res. 80, 510-521. doi: 10.1016/j.yqres.2013.09.004

Golterman, H. L. (1995). The role of the ironhydroxide-phosphate-sulfide system in the phosphate exchange between sediments and overlying water. Hydrobiologia 297, 443-454. doi: 10.1007/bf00033500

Golterman, H. L. (2001). Fractionation and bioavailability of phosphates in lacustrine sediments: a review. Limneica 20, 15-29.

Hill, C. A., and Forti, P. (1997). Cave minerals of the world. 2nd Edn, ed. A. L. Huntsville (United States: National Speleological Society).

Isola, I., Mazzarini, F., Molli, G., Piccini, L., Zanella, E., Zanchetta, G., et al. (2021). New chronological constraints from hypogean deposits for Late Pliocene to recent morphotectonic history of the Alpi Apuane (NW Tuscany, Italy). Geosciences 2021:65. doi: 10.3390/geosciences 11020065

Lu, H., Wan, J., Li, J., Shao, H., and Wu, L. (2016). Periphytic biofilm: a buffer for phosphorus precipitation and release between sediments and water. Chemosphere 144, 2058-2064. doi: 10.1016/j.chemosphere.2015. 10.129

Mantelli, F., Lotti, L., Montigiani, A., and Piccini, L. (2015a). Chimica delle acque del Complesso Carsico del Monte Corchia. Acta Apuana 11, 33-45.

Mantelli, F., Piccini, L., D'Elia, A., and Montigiani, A. (2015b). Risultati di analisi chimiche preliminari sulle patine nere nel Complesso carsico del Monte Corchia e in altre grotte italiane. Acta Apuana 2012, 63-72.

Molli, G., and Vaselli, L. (2006). "Structures, interference patterns, and strain regime during midcrustal deformation in the Alpi Apuane (Northern
Apennines, Italy)," in Styles of Continental Contraction, eds S. Mazzoli and R. W. H. Butler (United States: Geological Society of America), doi: 10.1130/ 2006.2414(05

Montigiani, A., Lotti, L., Bianucci, P., and Manelli, F. (1998). Studio e monitoraggio dell'Antro del Corchia (Stazzema-Lucca), individuazione della sua capacità di fruizione compatibile con l'ecosistema ipogeo. ARPAT. 1998:37.

Oelkers, E. H., and Valsami-Jones, E. (2008). Phosphate mineral reactivity and global sustainability. Elements 4, 83-87. doi: 10.2113/gselements.4.2.83

Onac, B. P., and Forti, P. (2011). Minerogenetic mechanisms occurring in the cave environment: an overview. IJS 40, 79-98. doi: 10.5038/1827-806x.40.2.1

Onac, B. P., Mylroie, J. E., and White, W. B. (2001). Mineralogy of cave deposits on San Salvador island, Bahamas. Carbonates Evaporites 16, 8-16. doi: 10.1007/ bf03176222

Piccini, L. (1998). Evolution of karst in the Apuan Alps (Italy): relationships with the morphotectonic history. Suppl. Geografia Fis. Dinam. Quat. 3, 21-31.

Piccini, L. (2011). Speleogenesis in highly geodynamic contexts: the quaternary evolution of Monte Corchia multi-level karst system (Alpi Apuane. Italy). Geomorphology 134, 49-61. doi: 10.1016/j.geomorph.2011. 06.005

Piccini, L., Zanchetta, G., Drysdale, R., Isola, I., and Bruschi, G. (2005). Depositi fisici e chimici delle grotte delle Alpi Apuane - Atti del Convegno "Le grotte raccontano: un milione di anni di storia naturale conservato nei sistemi carsici delle Alpi Apuane", Castelnuovo Garfagnana (Lu) 11-12 dicembre 2004. Memor. Istit. Ital. Speleol. 18, $101-118$.

Piccini, L., Zanchetta, G., Drysdale, R. N., Hellstrom, J., Isola, I., Fallick, A. E., et al. (2008). The environmental features of the Monte Corchia cave system (Apuan Alps, central Italy) and their effects on speleothem growth. IJS 37, 153-172. doi: 10.5038/1827-806x.37.3.2

Regattieri, E., Zanchetta, G., Drysdale, R. N., Isola, I., Hellstrom, J., and Dallai, L. (2014). Lateglacial to Holocene record ( $\mathrm{Ba}, \mathrm{Mg}$, Sr) from Corchia Cave (Apuan Alps, central Italy): paleoenvironmental implications. J. Quat. Sci. 29, 381-392. doi: $10.1002 /$ jqs.2712

Rossi, C., Lozano, R. P., Isanta, N., and Hellstrom, J. (2010). Manganese stromatolites in caves: el Soplao (Cantabria, Spain). Geology 38, 1119-1122.

Zanchetta, G., Drysdale, R. N., Hellstrom, J. C., Fallick, A. E., Isola, I., Gagan, M. K., et al. (2007). Enhanced rainfall in the Western Mediterranean during deposition of sapropel S1: stalagmite evidence from Corchia cave (Central Italy). Quat. Sci. Rev. 26, 279-286. doi: 10.1016/j.quascirev.2006. 12.003

Conflict of Interest: The authors declare that the research was conducted in the absence of any commercial or financial relationships that could be construed as a potential conflict of interest.

Copyright (c) 2021 Piccini, Nannoni, Costagliola, Paolieri and Vigiani. This is an open-access article distributed under the terms of the Creative Commons Attribution License (CC BY). The use, distribution or reproduction in other forums is permitted, provided the original author(s) and the copyright owner(s) are credited and that the original publication in this journal is cited, in accordance with accepted academic practice. No use, distribution or reproduction is permitted which does not comply with these terms. 